Article

\title{
"Nature-like" Cryoimmobilization of Phototrophic Microorganisms: New Opportunities for Their Long-Term Storage and Sustainable Use
}

\author{
Olga Senko ${ }^{1,2}$, Nikolay Stepanov ${ }^{1,2}$ (D), Olga Maslova ${ }^{1}$ and Elena Efremenko ${ }^{1,2, *(D)}$ \\ 1 Faculty of Chemistry, Lomonosov Moscow State University, 119991 Moscow, Russia; \\ senkoov@gmail.com (O.S.); na.stepanov@gmail.com (N.S.); olga-still@mail.ru (O.M.) \\ 2 N.M. Emanuel Institute of Biochemical Physics, Russian Academy of Sciences, 119334 Moscow, Russia \\ * Correspondence: elena_efremenko@list.ru; Tel.: +7-495-939-3170; Fax: +7-495-939-5417
}

check for

updates

Citation: Senko, O.; Stepanov, N.;

Maslova, O.; Efremenko, E.

"Nature-like" Cryoimmobilization of Phototrophic Microorganisms: New Opportunities for Their Long-Term Storage and Sustainable Use. Sustainability 2022, 14, 661. https:// doi.org/10.3390/su14020661

Academic Editors: Sunil Kumar, Pooja Sharma and Deblina Dutta

Received: 26 November 2021

Accepted: 5 January 2022

Published: 7 January 2022

Publisher's Note: MDPI stays neutral with regard to jurisdictional claims in published maps and institutional affiliations.

Copyright: (c) 2022 by the authors. Licensee MDPI, Basel, Switzerland. This article is an open access article distributed under the terms and conditions of the Creative Commons Attribution (CC BY) license (https:// creativecommons.org/licenses/by/ $4.0 /)$.

\begin{abstract}
It was found that immobilization of cells in poly(vinyl alcohol) (PVA) cryogel can be successfully applied for concurrent cryoimmobilization, cryoconservation and long-term storage of the cells of various phototrophic microorganisms (green and red microalgae, diatoms and cyanobacteria). For the first time, it was shown for 12 different immobilized microalgal cells that they can be stored frozen for at least 18 months while retaining a high level of viability $(90 \%)$, and can further be used as an inoculum upon defrosting for cell-free biomass accumulation. Application of cryoimmobilized Chlorella vulgaris cells as inocula allowed the loading of a high concentration of the microalgal cells into the media for free biomass accumulation, thus increasing the rate of the process. It was shown that as minimum of 5 cycles of reuse of the same immobilized cells as inocula for cell accumulation could be realized when various real wastewater samples were applied as media for simultaneous microalgae cultivation and water purification.
\end{abstract}

Keywords: phototrophic microorganisms; cryoimmobilization; poly(vinylalcohol) cryogel; cryoconservation; wastewater treatment; microalgal inoculum; long-term storage

\section{Introduction}

Interest in biotechnological developments based on the use of microalgae and cyanobacteria cells has not decreased in recent years, but has even increased [1,2], since these cells are attractive for solving many problems of ecology and biocatalysis in the interests of sustainable ecosystem development. Cyanobacteria and microalgae are both used as a valuable source of proteins, vitamins and polyunsaturated fatty acids for humans or for the purpose of enriching animal feed with protein, vitamins and trace elements [3]. The effective use of cyanobacteria and microalgae as a source of omega- 3 fatty acids, which are used in medicine for the treatment of cardiovascular diseases, asthma, migraines, arthritis, psoriasis, etc. has been shown. The biomass of these phototrophic microorganisms can also be used as a raw material for the production of fuel and additives to it (ethanol, butanol, biogas, biodiesel, hydrogen) [4,5]. Some microalgae and cyanobacteria can be used in bioindication to assess the level of environmental pollution by aquaculture wastewater [6].

Of particular interest are processes based on the use of microalgae and cyanobacteria for the purification of industrial, agricultural and domestic wastewater, with further processing of the accumulated biomass of phototrophic microorganisms acting as a source of bio-renewable raw materials [7]. At the same time, such strings serve as an excellent medium for the cultivation of phototrophic cells, allowing the maintenance of mixotrophic conditions, enhancing the growth rate of the microalgal cells [8] This allows both a reduction in the cost of biomass production and the solving of several ecological issues of wastewater treatment, which is, in turn, a part of the successful solving of the general tasks of sustainable environmental development. However, the cultivation of microalgae under 
such conditions is complicated by the inconstancy of the wastewater composition, and by the presence of toxicants which can inhibit microalgal cell growth [9]. Therefore, using immobilized microalgal cells as inocula looks like an attractive approach to improving the characteristics of microalgae wastewater treatment [10]. The advantages of this approach are as follows: the immobilization stabilizes the metabolic activity of the cells and allows introduction into the medium of an inoculum with a high concentration of cells uniformly distributed within the carrier; this ensures favorable mass transfer conditions for all the cells and causes an essential increase in the accumulation rate of the biomass of the free cells of filial generations [11,12].

Interestingly, the self-immobilization of phototrophic cells is a preferable natural state of the microorganisms. Microalgae assume the form of polymicrobial aggregates at the interface [13]. The materials that hold these cells together to form a heterogeneous matrix are synthesized and excreted by microalgae themselves into their immediate environment [14]. The lifestyle of microalgae cells in the frame of aggregates is completely different from the lifestyle of suspended cells. For the active use of stably functioning microalgae and cyanobacteria cells in immobilized form, the use of various carriers and methods of immobilization is presently in practice, as follows: sorption, inclusion of gel structures in pores, chemical stitching to carriers, etc. [15-17]. Analysis of known technical solutions as part of the most successful approaches to immobilized microalgae development allows the formulation of the following main requirements for the carrier of the cells to be used as an inoculum for biomass accumulation in wastewater: firstly, the carrier should ensure favorable conditions for mass transfer processes while preserving the high metabolic activity of the phototrophic cells; secondly, it should not hinder the microalgal cells of filial generations from leaving the polymeric matrix and accumulating in a suspension form in the culture medium outside the carrier.

In the view of all the mentioned characteristics, the application of poly(vinyl alcohol) (PVA) cryogel in microalgal cell immobilization seems to us to be prospective for a variety of reasons. These include the (typically high) pore size of this carrier, which are formed in the course of the "nature-like" structuring of high-molecular compounds via a simple freeze-thaw treatment, and which can be controlled depending on the requirements of the target process. The cryogel itself has a high elasticity and mechanical strength, and the pore structure is quite regular due to the use of a synthetic polymer with controllable characteristics [18,19]. The PVA cryogel has been successfully used for the immobilization of microorganism cells of various types (yeast, bacteria and fungi) [4,11,20-24], ensuring the high viability of these cells even upon their long-term (several years) frozen storage in an immobilized form [20,23]. The possible long-term storage of cells immobilized in PVA cryogel makes another aspect of the application of this carrier for phototrophic microorganisms interesting as an alternative solution used in collections to preserve the biological diversity of microalgae cells.

Generally, the possible negative influence of cryoconservation on phototrophic cells is well known, however the techniques were reported [25] to successfully preserve the viability and productivity of microalgal cells, involving freezing of the cells with the application of various cryoprotectants (dimethyl sulfoxide, methanol, glycerol, etc.) and very low temperatures (down to temperature of liquid nitrogen) [26]. However, some of the cryoprotectants possess cytotoxicity or non-effectiveness, and the storage of cells at the temperature of liquid nitrogen requires power-consuming and expensive cryogenic equipment.

Therefore, a more practicable approach to cryoconservation can be realized via cryoimmobilization of the phototrophic cells in appropriate polymeric gel carriers. The polymer in such systems should play both the role of cryoprotectant and the base of the matrix containing the cells. In order to produce such a matrix with this technique, the cell suspension in the polymer solution can be frozen at a temperature within the range of $-15--70^{\circ} \mathrm{C}$, which is much higher than that of liquid nitrogen. 
Immobilization of the microalgal cells into the PVA cryogel matrix appears more prospective due to the following reasons. First, PVA is known for its cryoprotective properties [27-29], and second, the genuinely successful storage of various microbial cells immobilized in PVA cryogel for two years at $-20{ }^{\circ} \mathrm{C}$ without an essential loss of their metabolic and catalytic activity has been previously established [20,23,30].

Thus, the main tasks of this work were the following: firstly, to study the possibility of the obtainment and long-term storage of various phototrophic microorganisms immobilized in PVA cryogel; secondly, to evaluate the biochemical composition of free cells accumulated using an immobilized inoculum. Another goal was to analyze the subsequent use of such immobilized cells as an inoculum for cultivation in various types of wastewater for the accumulation of free biomass of microalgal cells (using the example of Chlorella vulgaris culture). In this work, a fairly large variety of cultures were used as objects for cryopreservation. It is known that eukaryotes are more complex organisms than prokaryotes, so it seemed to us to be most interesting and important to test the investigated approach based on cell immobilization in a PVA cryogel with a wider use of eukaryotes [31-34]. The choice in favor of cyanobacteria of the filamentous type was made by us, based on similar considerations. It is also known that cyanobacteria of the filamentous type have a lower survival rate than many other cyanobacteria during cryoconservation, including in situations when they are frozen in liquid nitrogen $[32,35,36]$.

\section{Materials and Methods}

\subsection{Strains and Media}

The following cell cultures were used in this research: C. vulgaris [Beier.] rsemsu Chv-20/11, Dunaliella salina rsemsu Dns-26/11, Nannochloropsis sp. rsemsu N-1/11-B, Chlamydomonas sp. rsemsu Chlam-10/11, Chlorococcum sp. rsemsu Ccc-24/11, Cosmarium sp. rsemsu Cos-19/11, Galdieria partita rsemsu Gp-17/11, Haematococcus pluvialis Flotow em. Wille rsemsu Hp-1/11, Thalassiosira weissflogii rsemsu Twl-11/11, Nostoc sp. rsemsu Nss-14/11, Arthrospira platensis (Nordst.) Geitl. rsemsu 1/02 and Gloeotrichia echinulata rsemsu Ge-15/11, all obtained from the IBCP RAS collections.

Cultivation of the microalgal cells was performed in the corresponding typical media recommended for the cells' specific conditions [4] at $25^{\circ} \mathrm{C}$ and under round-the-clock lighting with Osram Fluora 77 luminescent lamps (30 W, Munich, Germany). The OD 540 of the cell suspensions was controlled to investigate the kinetic curve of growth.

The biomass of microalgal cells was separated from the culture media by centrifugation (4000× $g, 15 \mathrm{~min})$, using an Avanti J 25 centrifuge (Beckman Coulter, Indianapolis, IN, USA). Immobilization of cells was conducted using the patented procedure [37]. Poly(vinyl alcohol) 16/1 (84 kDa) was purchased from Sinopec Corp. (Beijing, China). The biomass of phototrophic microorganisms immobilized in PVA cryogel was stored at $-70^{\circ} \mathrm{C}$ using a DS 78 compact freezer (Dairei Asia Sdn. Bhd, Kuala Lumpur, Malaysia) over 18 months, and was then slowly defrosted via the following two stages: the first one, at $-20{ }^{\circ} \mathrm{C}$, using a GN 3613 freezer (Liebherr, Biberach, Germany) for $3 \mathrm{~h}$, and the second one, at $8 \pm 2{ }^{\circ} \mathrm{C}$ in a 2201 Combicoldrac II refrigerator (LKB Instruments Haglund, Saffle, Sweden).

For multiple uses of immobilized $C$. vulgaris cells under batch conditions after each working cycle, the granules were washed with a sterile $0.9 \%$ sodium chloride solution and loaded in the reactor with a new portion of the culture medium (horticultural, municipal or milk plant wastewater).

In order to accumulate the C. vulgaris biomass we used municipal wastewater (Moszelenkhoz, Moscow, Russia), wastewater from a milk processing plant (OOO Ostankinsky Molochny Kombinat, Moscow, Russia) and the horticultural water from a gardening facility (Ostankinsky sovkhoz dekorativnogo sadovodstva, Moscow, Russia). The chemical content (lipids/proteins/carbohydrates, $\mathrm{g} / \mathrm{L}$ ) and $\mathrm{pH}$ of the wastewater samples were as follows: milk plant-0.35/0.28/0.56 ( $\mathrm{pH} 6.8$ ); horticultural water-0.17/0.13/0.27 (pH 6.5); municipal water-0.08/0.06/0.04 (pH 7.1). The cultivation was performed in $750 \mathrm{~mL}$ Erlenmeyer flasks with $100 \mathrm{~mL}$ of the cultivation medium. The cells were harvested after cultivation 
using an Avanti J 25 centrifuge (Beckman Coulter, Indianapolis, IN, USA) at 8000 rpm for $10 \mathrm{~min}$.

\subsection{Analytical Methods}

The biochemical composition of the cell biomass (content of lipids, proteins, hydrocarbons) was analyzed using the standard methods described previously [4]. For the thermal treatment $\left(121^{\circ} \mathrm{C}, 0.5 \mathrm{~h}\right)$, the wet biomass (100 g cell dry weight $\left.(\mathrm{CDW}) / \mathrm{L}\right)$ was suspended in the $0.1 \mathrm{M}$ citrate buffer with $\mathrm{pH}$ 5.0.

The lipid extraction was carried out by the treating of wet concentrated biomass with $n$-hexane via the known method [38]. Upon the extraction of the lipids, the microalgal cell debris was removed from the medium via centrifugation (8000 rpm during $10 \mathrm{~min}$ ), and was used for the detection of protein and hydrocarbon content by well-known methods [4].

The dry weight of cell biomass (CDW) was determined via a standard gravimetrical method by drying a sample at $105^{\circ} \mathrm{C}$ to a constant weight.

The concentration of intracellular adenosine triphosphate (ATP) was determined by the bioluminescent luciferin-luciferase method as described previously [30].

Chemical oxygen demand (COD), total suspended solids (TSS) content, total nitrogen (TN) content and total phosphorus (TP) content were measured by standard methods [39-42].

To determine the fluorescent characteristics of microalgal cell pigments, the obtained granules with immobilized cells were placed in a nutrient medium after thawing for a long period of storage. Further, appropriate measurements were carried out to determine the relative fluorescence variable $(\mathrm{Fv} / \mathrm{Fm})$ of the pigment of the cells according to a known technique [43]. Fluorescence excitation was performed at $455 \mathrm{~nm}$ with an electronic photomultiplier through a KS-18 filter. The intensity of chlorophyll fluorescence under the conditions of open reaction centers of the Photosystem II $\left(\mathrm{F}_{0}\right)$ and the maximum chlorophyll-fluorescence intensity under the conditions of completely closed reaction centers of Photosystem II (Fm) were measured at the intensity of an excitation light with a density of 0.8 and $6000 \mu \mathrm{mol}$ quanta $/\left(\mathrm{m}^{2} / \mathrm{s}\right)$, respectively. The potential efficiency of the primary photosynthesis processes (maximum photochemical quantum yield of Photosystem II) $\mathrm{Fv} / \mathrm{Fm}=\left(\mathrm{Fm}-\mathrm{F}_{0}\right) / \mathrm{Fm}, \mathrm{Fv}=\mathrm{Fm}-\mathrm{F}_{0}$ is the variable fluorescence. The fluorescence values are presented in relative units.

The $\mathrm{pH}$ value of the media and buffers prepared was measured potentiometrically using a Corning Pinnacle $530 \mathrm{pH}$ meter (Corning, Root, Switzerland).

The Reducing Power (RP) of microalgal biomass samples was determined in triplicate according to the described method [44]. Absorbance was measured at $700 \mathrm{~nm}$. Ascorbic acid (vitamin C) was used as a positive control. Results were expressed as mg vit C/g CDW.

Unsaturated fatty acids in lipids of microalgal biomass was analyzed using the published procedure [45] of gas chromatography-mass spectrometry on a 7820A gas chromatograph with a 5977B MSD Bundle with a 7820 GC mass detector (Agilent Technologies, Waldbronn, Germany).

To determine the standard deviation $( \pm S D)$ of the results, data were obtained in at least three independent experiments. Statistical analysis was realized using SigmaPlot (ver. 12.5, Systat Software Inc., San Jose, CA, USA). The one-way analysis of variance (abbreviated one-way ANOVA) was used. All pairwise multiple comparison procedures were undertaken using the Holm-Sidak method: overall significance level =0.05.

\section{Results}

3.1. Cryoimmobilization of Phototrophic Microbial Cells in PVA Cryogel and Their Long-Term Storage

Initially, the effect of immobilization in PVA cryogel was tested on the surviving chlorella cells, and if successful, it was decided to switch to using the same cryopreservation method for other phototrophs. 
To estimate the potential applicability of the cryoimmobilization technique to the different microalgal species, this approach was applied to 12 phototrophic microorganisms (Table 1). The samples of the immobilized cells were prepared at $-70{ }^{\circ} \mathrm{C}$ and stored at the same temperature for 18 months. Periodically, the samples of polymeric granules with entrapped cells were slowly thawed and were subsequently used as immobilized inocula for biomass accumulation in the typical media for autotrophic cell growth (Figure 1). The cell survival level was analyzed by the detection of intracellular ATP concentration in immobilized cells upon their thawing, and their opportunity to reproduce was controlled by the determination of the concentration of accumulated free cells in the medium. Percentage ratio (PRB) between biomass accumulated for $72 \mathrm{~h}$ in the media with immobilized inoculum after and before the cell storage for 18 months was specially calculated (Table 1).

Table 1. Characteristics of the immobilization process in PVA cryogel $\left(-70{ }^{\circ} \mathrm{C}\right)$ optimal for various phototrophic microorganisms.

\begin{tabular}{|c|c|c|c|}
\hline $\begin{array}{c}\text { Phototrophic } \\
\text { Microorganism Species }\end{array}$ & $\begin{array}{l}\text { Concentration of PVA Solution } \\
\text { Used for Cell Immobilization, \% }\end{array}$ & $\begin{array}{l}\text { Cell Biomass Concentration (CDW) } \\
\text { in the Immobilized Sample, \% }\end{array}$ & PRB * \% \\
\hline \multicolumn{4}{|c|}{ Green microalgae } \\
\hline C. vulgaris & 7.0 & 4.0 & $95 \pm 3$ \\
\hline Dunaliella salina & 8.0 & 4.3 & $94 \pm 4$ \\
\hline Nannochloropsis sp. & 7.5 & 3.8 & $93 \pm 4$ \\
\hline Chlamydomonas sp. & 6.5 & 4.3 & $90 \pm 3$ \\
\hline Chlorococcum sp. & 7.0 & 4.2 & $92 \pm 3$ \\
\hline Cosmarium sp. & 8.0 & 3.7 & $94 \pm 4$ \\
\hline \multicolumn{4}{|c|}{ Red microalgae } \\
\hline Galdieria partita & 8.0 & 4.1 & $91 \pm 3$ \\
\hline Haematococcus pluvialis & 7.0 & 4.3 & $92 \pm 3$ \\
\hline \multicolumn{4}{|c|}{ Diatoms } \\
\hline Thalassiosira weissflogii & 8.7 & 4.0 & $95 \pm 4$ \\
\hline \multicolumn{4}{|c|}{ Cyanobacteria } \\
\hline Nostoc sp. & 6.5 & 4.0 & $91 \pm 3$ \\
\hline Arthrospira platensis & 6.0 & 3.8 & $90 \pm 3$ \\
\hline Gloeotrichia echinulata & 8.5 & 3.7 & $93 \pm 4$ \\
\hline
\end{tabular}

* PRB is Percentage Ratio between Biomass accumulated in the media with immobilized inoculum after (Cs) and before $\left(C_{0}\right)$ its storage for 18 months, calculated as $L=C s / C_{0} \times 100 \%$. Biomass accumulation was performed for $72 \mathrm{~h}$.

The variations in the concentrations of PVA solution and cell biomass taken for mixing in the obtaining of granule samples with immobilized cells revealed the influence of these parameters on the final successful results, namely, values of intracellular ATP and PRB. Table 1 contains the experimentally established optimal conditions for the immobilization of the microorganisms in PVA cryogel. It was demonstrated that the suggested carrier and the applied immobilization technique ensure a high viability level of different microalgal cells (the average viability level was 90-95\%).

The high-enough levels of residual intracellular ATP concentrations in all the performed phototrophic cultures after their different periods of storage at $-70{ }^{\circ} \mathrm{C}$ in immobilized form as compared to the initial levels of same parameter obtained for immobilized cells without their storage are shown in Figure 1.

Additionally the levels of fluorescent characteristics of phototrophic cell pigments were analyzed for immobilized cells (upon long-term storage), in comparison with the same cells in a free form (Figure 2). It was shown that cryoimmobilization and storage result in a temporary decrease in the relative fluorescence values of most of the cells except for the Thallasiosira. However, the analyzed characteristics of immobilized cells restored up to the level of free cells during the further cultivation of the microalgae for 3 days (Figure 3 ). 

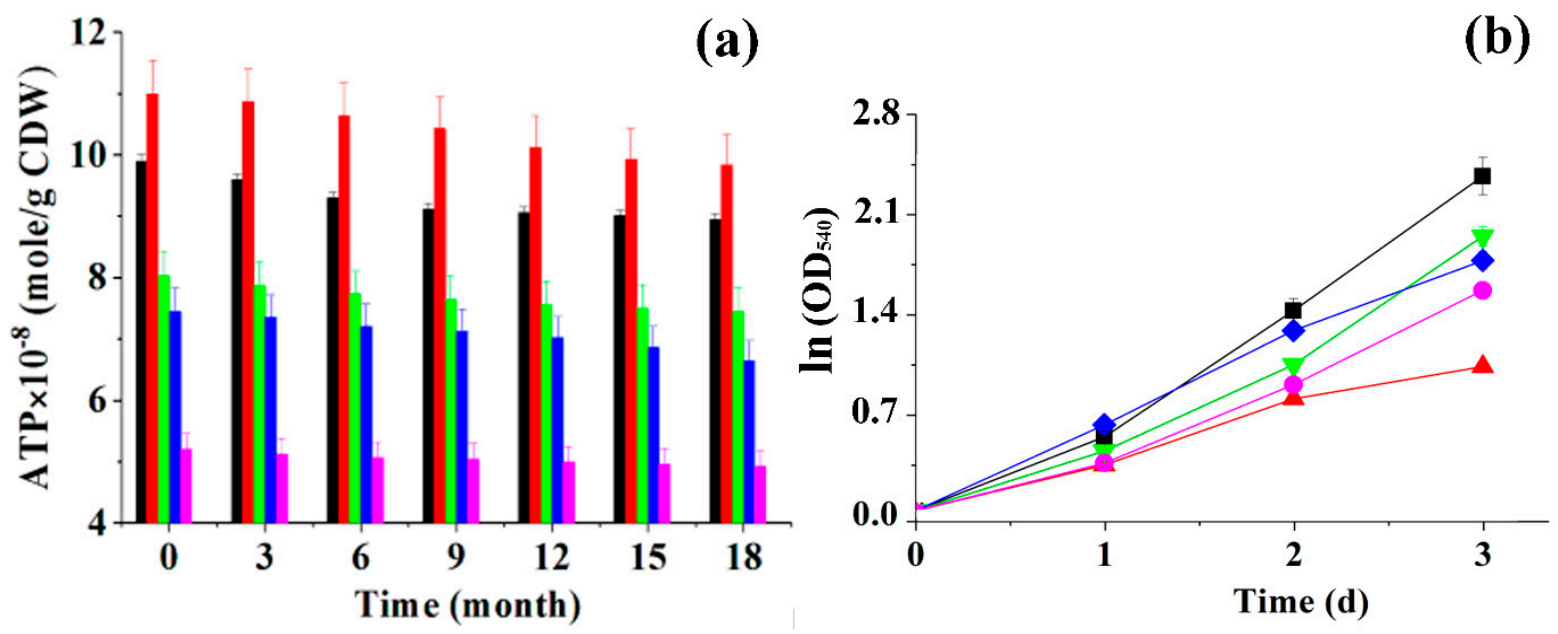

Figure 1. Changes in the concentration of ATP in microalgal cells immobilized in PVA cryogel during their storage for 18 months (a) and accumulation of free cell biomass during cultivation of immobilized cells as inoculum after storage for 18 months in media appropriate for certain type of culture (b), where Chlorella (black $\mathbf{\square})$, Nostoc (red $\mathbf{\Delta})$, Nannocnloropsis (green $\nabla$ ), Arthrospira (blue $\bullet$ ), Thallasiosira (magenta $)$.

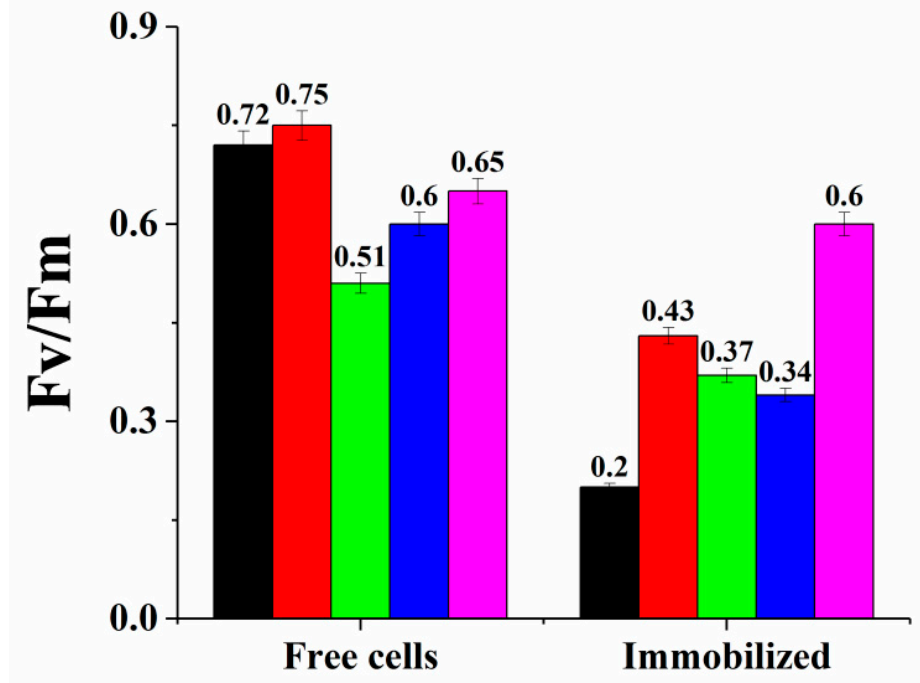

Figure 2. Relative variable fluorescence values of free and immobilized microalgal cells immediately after their defrosting upon 18 months of storage, where Chlorella (black $\mathbf{\square})$, Nostoc (red $\mathbf{\Delta}$ ), Nannocnloropsis (green $\nabla$ ), Arthrospira (blue $\diamond$ ), Thallasiosira (magenta $\bullet$ ).

The cellular biochemical composition of free phototrophic microbial cell biomass accumulated as result of the cultivation of immobilized inoculum, used after its storage for 18 months, was specially analyzed (Table 2).

In general, it was noted that the content of the main components of suspended cells obtained by cultivating the immobilized inoculum corresponded to similar characteristics typical for cells usually accumulated in the case of using a traditional free cell inoculum. Antioxidant activity in the microalgal free cell biomass was at a regular level.

Thus, it was shown for the first time that cryoimmobilization and cryoconservation can be united in the same stage of the applied approach to the long-term storage of cells of various microalgae, which can be further successively implemented as inocula to grow and accumulate the free cell biomass of the phototrophic microorganisms useful for treatment in various processes owing mainly to biochemical composition, which are similar to common suspended cells. 

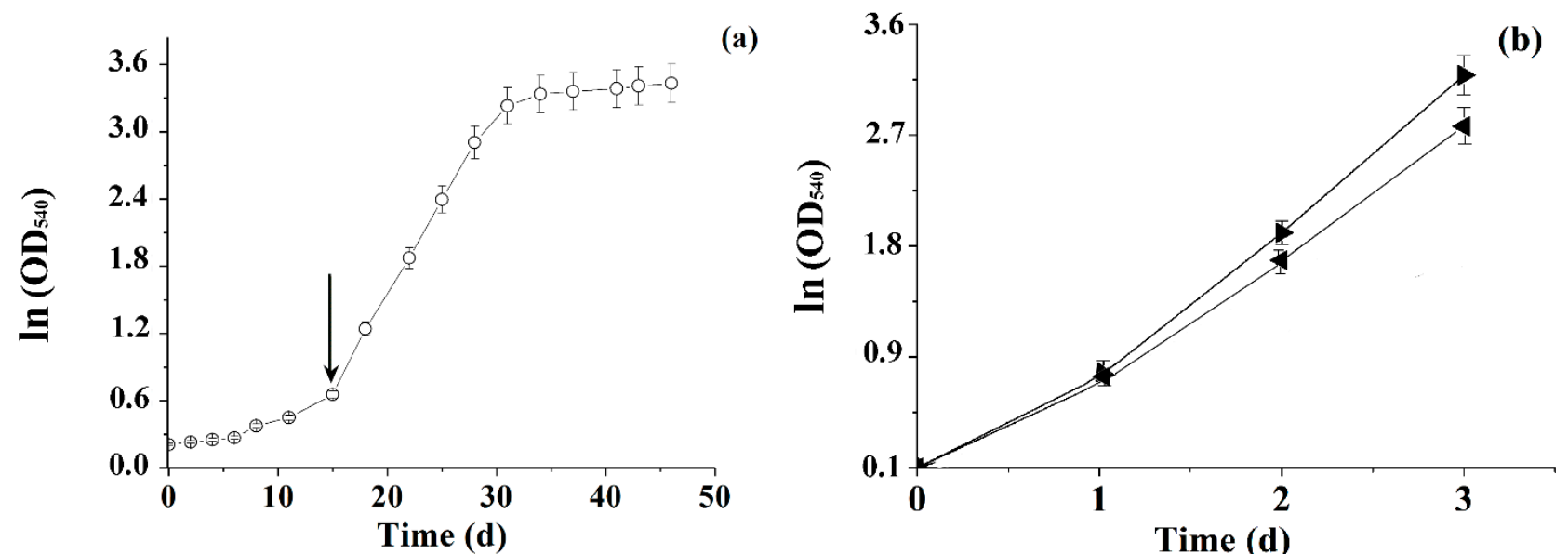

(c)

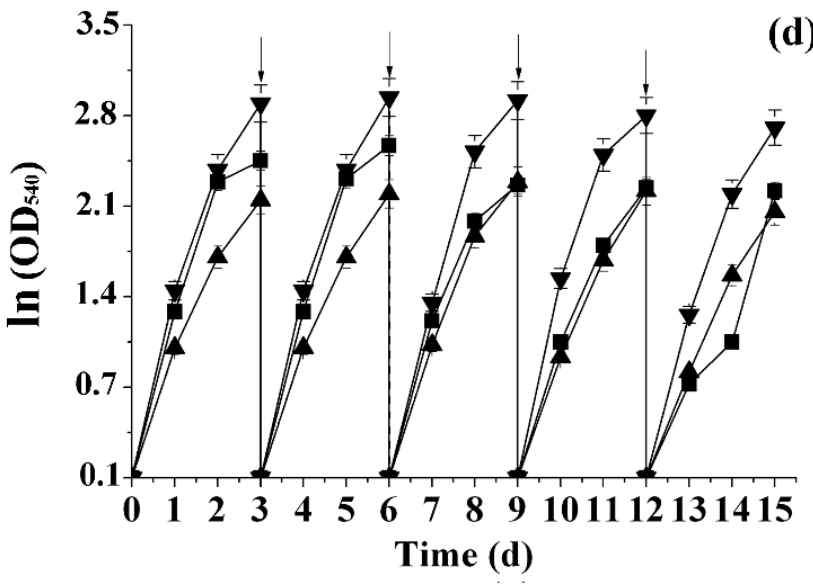

Figure 3. The kinetic curve of the autotrophic growth of C. vulgaris in the Tamiya medium in semi-logarithmic coordinates, the arrow marking the beginning of the most intensive biomass growth. (a). Free biomass accumulation during the cultivation of immobilized C. vulgaris cells in semilogarithmic coordinates: in a Tamiya medium with addition of $2 \mathrm{~g} / \mathrm{L}$ of glucose $(\boldsymbol{\nabla})$ or $2 \mathrm{~g} / \mathrm{L}$ of glycerol (4) (b). The PVA cryogel granules with the immobilized C. vulgaris cells before (left) and after (right) their use as inocula (c). Free biomass accumulation upon multiple uses of the immobilized inoculum in horticultural ( $\mathbf{\square})$, municipal $(\mathbf{\Delta})$ and milk plant $(\mathbf{\nabla})$ wastewater in semi-logarithmic coordinates. The arrows mark the time of inoculum transfer to the fresh medium. (d). The concentration of the cells in the initial inoculum was: $0.05 \pm 0.002 \mathrm{~g} \mathrm{CDW} / \mathrm{L}(\bigcirc), 1.17 \pm 0.08 \mathrm{~g} \mathrm{CDW} / \mathrm{L}(\varangle)$, and $1.1 \pm 0.05 \mathrm{~g} \mathrm{CDW} / \mathrm{L}(\boldsymbol{\nabla}, \mathbf{\square}, \mathbf{\Lambda}, \mathbf{\nabla})$.

Table 2. Biochemical composition of biomass of phototrophic microorganisms obtained using immobilized inoculates.

\begin{tabular}{cccc}
\hline $\begin{array}{c}\text { Phototrophic } \\
\text { Microorganism Species }\end{array}$ & $\begin{array}{c}\text { Lipids/ } \\
\text { Proteins/ } \\
\text { Hydrocarbons, } \%\end{array}$ & $\begin{array}{c}\text { Unsaturated Fatty Acids, \% from } \\
\text { Total Fatty Acids in Lipid Content }\end{array}$ & $\begin{array}{c}\text { RP, } \\
\text { mg vit C/g CDW }\end{array}$ \\
\hline \multicolumn{4}{c}{ Green microalgae } \\
C. vulgaris & $16.5 \pm 0.8 / 7.0 \pm 0.3 / 55.6 \pm 2.7$ & $53.6 \pm 2.6$ & $0.01 \pm 0.0004$ \\
Dunaliella salina & $9.1 \pm 0.4 / 5.4 \pm 0.2 / 69.7 \pm 3.4$ & $26.3 \pm 1.3$ & $0.02 \pm 0.001$ \\
Nannochloropsis sp. & $25.0 \pm 1.2 / 7.0 \pm 0.3 / 54.9 \pm 2.7$ & $43.6 \pm 2.1$ & $1.21 \pm 0.06$ \\
Chlamydomonas sp. & $48.2 \pm 2.4 / 17.0 \pm 0.8 / 21.3 \pm 0.9$ & $47.4 \pm 2.3$ & $0.42 \pm 0.02$ \\
Chlorococcum sp. & $19.3 \pm 0.9 / 52.7 \pm 2.6 / 17.2 \pm 0.8$ & $18.4 \pm 0.9$ & $1.09 \pm 0.05$ \\
Cosmarium sp. & $6.7 \pm 0.3 / 19.9 \pm 0.9 / 58.4 \pm 2.9$ & $0.05 \pm 0.002$ \\
\hline
\end{tabular}


Table 2. Cont.

\begin{tabular}{|c|c|c|c|}
\hline $\begin{array}{l}\text { Phototrophic } \\
\text { Microorganism Species }\end{array}$ & $\begin{array}{c}\text { Lipids/ } \\
\text { Proteins/ } \\
\text { Hydrocarbons, \% }\end{array}$ & $\begin{array}{l}\text { Unsaturated Fatty Acids, \% from } \\
\text { Total Fatty Acids in Lipid Content }\end{array}$ & $\begin{array}{c}\text { RP, } \\
\text { mg vit } \mathrm{C} / \mathrm{g} \mathrm{CDW}\end{array}$ \\
\hline \multicolumn{4}{|c|}{ Red microalgae } \\
\hline Galdieria partita & $7.5 \pm 0.3 / 41.8 \pm 2.0 / 50.0 \pm 2.4$ & $17.5 \pm 0.8$ & $1.05 \pm 0.05$ \\
\hline Haematococcus pluvialis & $15.6 \pm 0.7 / 22.2 \pm 1.1 / 52.7 \pm 2.6$ & $30.6 \pm 1.5$ & $3.6 \pm 0.1$ \\
\hline \multicolumn{4}{|c|}{ Diatoms } \\
\hline Thalassiosira weissflogii & $42.1 \pm 2.1 / 30.6 \pm 1.5 / 22.3 \pm 1.2$ & $9.4 \pm 0.4$ & - \\
\hline \multicolumn{4}{|c|}{ Cyanobacteria } \\
\hline Nostoc sp. & $9.2 \pm 0.4 / 20.4 \pm 0.9 / 52.3 \pm 2.6$ & $15.6 \pm 0.7$ & $0.83 \pm 0.04$ \\
\hline Arthrospira platensis & $19.0 \pm 0.9 / 40.9 \pm 1.9 / 40.8 \pm 1.9$ & $22.9 \pm 1.1$ & $1.46 \pm 0.07$ \\
\hline Gloeotrichia echinulata & $15.8 \pm 0.7 / 32.7 \pm 1.6 / 48.5 \pm 2.4$ & $33.4 \pm 1.6$ & - \\
\hline
\end{tabular}

\subsection{Accelerating the Accumulation of Biomass of Chlorella Vulgaris via the Use of} Immobilized Inoculum

The possible effect of microalgae immobilization on the growth rate of progeny cells was studied using the example of C. vulgaris. Initially, the kinetic curve of autotrophic growth of the $C$. vulgaris cells was studied in a Tamiya medium typical for chlorella cell growth, with an initial free cell inoculum concentration of $0.05 \pm 0.002 \mathrm{~g} \mathrm{CDW} / \mathrm{L}$ (Figure 3a).

It was shown that the rate of free cell biomass growth reached its maximum when the concentration of $0.35 \pm 0.01 \mathrm{~g} \mathrm{CDW} / \mathrm{L}$ was reached in the medium with an initial free inoculum. It appeared that the biomass growth rate depended on the cell concentration in the medium (Figure 3a). This effect was also noted by other researchers [46,47], and it was observed, most probably, due to the intracellular interactions in the frame of the quorum sensing (QS) mechanism in microalgal cells. The increase in cell concentration within limited volume results in a reduction of the intracellular distance and an increase in the local concentration of the inductor molecules of the QS mechanism [48].

It is known that the introduction of additional components into the mineral medium can cause an essential increase in the biomass growth rate [49]. In order to estimate the accumulation rate of the $C$. vulgaris free cell biomass in the presence of a certain concentration of inocula, the immobilized inoculum with a concentration of cells higher than that in the experiment with free cell inoculum (Figure 3a) was applied in a further investigation (Figure 3b). For this purpose, the PVA cryogel granules containing the immobilized C. vulgaris cells were introduced into the Tamiya medium with additional organic substrates ( $2 \mathrm{~g} / \mathrm{L}$ of glucose or $2 \mathrm{~g} / \mathrm{L}$ of glycerol) (Figure $3 \mathrm{~b}$ ), and the comparative estimation of similar growth in a Tamiya medium under autotrophic conditions (Figure 1) was conducted.

It was established that the use of the immobilized inocula under the mixotrophic conditions allowed a notable increase in the cell-free biomass accumulation within $72 \mathrm{~h}$ as compared both to free-cell inocula (Figure 3a) and to the immobilized inoculum applied in the Tamiya medium without special organic additives (Figure 1). It was found that after their use, the granules containing the cryoimmobilized inoculum were practically unchanged in appearance; they could be easily separated from the medium and multiply reused for further biomass accumulation (Figure 3c).

It was reasonable to suppose that the observed effects can be achieved in case of biomass growth in other media, e.g., wastewater samples. In the present, the possibility of multiple uses of $C$. vulgaris cells immobilized in PVA cryogel as inocula for biomass accumulation was demonstrated in wastewater of different types (Figure 3d). The most intensive biomass accumulation was observed within the first $48 \mathrm{~h}$ of cultivation. The great- 
est biomass amount was produced in milk plant wastewater. The biomass accumulation was accompanied with an efficient purification of wastewater (Table 3).

Table 3. Wastewater baseline characteristics and removal efficiency of components after $72 \mathrm{~h}$ of Chlorella biomass cultivation with the use of immobilized inoculum.

\begin{tabular}{ccccccccc}
\hline \multirow{2}{*}{ Wastewater } & \multicolumn{3}{c}{ Baseline Characteristics (mg/L) } & \multicolumn{4}{c}{ Removal Efficiencies after 72 h (\%) } \\
\cline { 2 - 10 } & COD & TSS & TN & TP & COD & TSS & TN & TP \\
\hline Horticultural & $780 \pm 28$ & $70 \pm 3$ & $47.6 \pm 2.1$ & $7.3 \pm 0.2$ & $81 \pm 3$ & $79 \pm 3$ & $84 \pm 3$ & $93 \pm 3$ \\
Municipal & $230 \pm 9$ & $50 \pm 2$ & $38.4 \pm 1.6$ & $4.6 \pm 0.2$ & $88 \pm 4$ & $94 \pm 4$ & $91 \pm 4$ & $95 \pm 4$ \\
Milk plant & $1400 \pm 61$ & $350 \pm 15$ & $60.0 \pm 2.7$ & $8.0 \pm 0.3$ & $92 \pm 4$ & $76 \pm 3$ & $78 \pm 4$ & $88 \pm 3$ \\
\hline
\end{tabular}

It was revealed that upon five cycles of cryoimmobilized inoculum reuse, the amount of $C$. vulgaris biomass could be in the range of $4.7 \pm 0.2$ up to $6.1 \pm 0.3 \mathrm{~g} C D W / \mathrm{L}$, depending on the wastewater type. Note that the productivity (in terms of accumulated biomass amount) of the cryoimmobilized inoculum decreased by no more than $10 \%$ after 5 reuse cycles.

\section{Discussion}

Taking into account the obtained results, it was found that the cryoimmobilization of phototrophic microbial cells (green and red microalgae, diatoms and cyanobacteria) in PVA cryogel is suitable for cryoconservation of the cells (Table 1). The cryoconservation of the phototrophic microorganism cells in the suggested approach occurs simultaneously with their cryoimmobilization in PVA cryogel, and ensures long-term storage of the cells for at least 18 months while preserving their high viability. This immobilization technique can be successfully applied in the cryoconservation of a wide-enough range of phototrophic microorganism cells, and thus has a claim to a certain universality. Thus, it may be attractive for microalgae collections existing in different countries, since the method does not require the use of an additional cryoprotectant, for example DMSO, penetrating cells and acting as a toxicant, nor does it require the use of super-low temperatures for cell storage.

The results showed that the previously well-studied porosity of the PVA cryogels $[18,19,29]$ is such that the mass transfer of microalgae cells has no limitations, so that the cells cryoimmobilized are well supplied with substances necessary for their growth and propagation, and the daughter cells can exit from the matrix into the cultivation medium. Thus, using the inoculum of cells cryoimmobilized in the PVA cryogel under used conditions is prospective for microalgae biomass accumulation (Figures 1 and 3).

The cell biomass accumulated using inocula such as those immobilized in PVA cryogel possessed a biochemical composition (Table 2) that can be applied for producing various commercially valuable substances. The performed studies have shown that the application of cryoimmobilized inocula can allow an improvement of the accumulation rate of $C$. vulgaris cell biomass when using wastewater of various origins as media for microalgae cultivation (Table 3). The obtained results can be further used for creating biotechnological complexes involving efficient biocatalytic processes aimed at microalgae biomass accumulation accompanied by treatment of wastewater of various origins, with a further transformation of this biomass into various target products, while providing a possibility of the long-term storage of viable immobilized cells.

It is known that when certain concentrations are reached in a population, the cells of microorganisms can change the nature of their behavior due to the manifestation of the QS effect [50]. Microalgae and cyanobacteria cells are no exception to this rule [51,52]. The immobilization of microalgae cells in PVA cryogel allows the creation and cultivation of populations with a high density of cells with their simultaneous uniform distribution over the volume of the nutrient medium. In this regard, the kinetics of cell growth in the case of using an inoculate loaded into the nutrient medium in an immobilized form can be 
regulated and can reach a level (Figure 3b) that is characteristic of the growth curves of free cells at their increased concentration in the medium (Figure 3a).

The demonstrated approach to cryoconservation of microalgae cells does not require the use of special low-temperature equipment and thermal insulation, as is the case when liquid nitrogen is applied for the long-term cryoconservation of analogue cell samples. Therefore this approach to storing large quantities of frozen samples under easily reproducible conditions allows the use of equipment routinely applied in biotechnology. The demonstrated approach is a clear winner in comparison with another example (Table 4), involving the immobilization of the diatoms (Haslea ostrearia cells) in Ca-alginate gel, followed by its impregnation with a $0.7 \mathrm{M}$ solution of sucrose (used as a cryoprotectant), freezing at $-80^{\circ} \mathrm{C}$, and subsequent storage in liquid nitrogen [53].

Our approach also stands well in comparison with another example [54], which involves the initial immobilization of the cells of Rivularia aquatic and Gloeotrichia echinulata cyanobacteria in Ca-alginate gel followed by freezing and storage at $-20{ }^{\circ} \mathrm{C}$. It was shown that upon the storage of such an immobilized inoculum for 1 year at the mentioned temperature, the resulting viability of these two cell cultures was $47 \%$ and $49 \%$, respectively. Such a low level of cell viability shows that the polymer matrix used in this technique did not ensure the desired level of cell cryoprotection.

Table 4. Various cryopreservation methods of microalgal biomass and cell viability after longterm storage.

\begin{tabular}{|c|c|c|c|}
\hline Strain [Reference] & Cryopreservation of Biomass * & Storage Time & Cell Viability, \% \\
\hline $\begin{array}{l}\text { C. vulgaris } 211-11 b \\
\text { [55] }\end{array}$ & $\begin{array}{c}\text { Freezing and storage at }-80{ }^{\circ} \mathrm{C} \text { using a freezing } \\
\text { container or a simple polystyrene box. Cryoprotectant } \\
\text { mixture: } 10 \%(v / v) \text { DMSO, } \\
10 \%(v / v) \text { EG, and } 10 \%(w / v) \text { L-proline. }\end{array}$ & $24 \mathrm{~h}$ & $63 \pm 2$ \\
\hline $\begin{array}{l}\text { C. vulgaris C-27 } \\
{[56]}\end{array}$ & $\begin{array}{c}\text { Freezing at }-40{ }^{\circ} \mathrm{C} \text { for } 4 \mathrm{~h} \text { and then storage } \\
\text { in liquid nitrogen } \\
\text { Cryoprotectant mixture: } 5 \%(v / v) \text { DMSO, } \\
5 \%(v / v) \mathrm{EG} \text {, and } 5 \%(w / v) \text { L-proline. }\end{array}$ & 15 years & $54 \pm 1$ \\
\hline \multirow[t]{2}{*}{ Chlorella sp. [57] } & $\begin{array}{c}\text { Cryoprotectant: } 10 \%(v / v) \text { DMSO } \\
\text { Cooling-freezing-cryopreservation: gradual decrease } \\
\text { of temperature from }+25^{\circ} \mathrm{C} \text { to }-30{ }^{\circ} \mathrm{C} \text {. } \\
\text { with rate of } 1{ }^{\circ} \mathrm{C} \mathrm{min} \text { min }^{-1}\end{array}$ & 12 months & 77.5 \\
\hline & $\begin{array}{l}\text { Cryoprotectant: } 5 \%(v / v) \text { methanol. } \\
\text { Direct freezing in liquid nitrogen }\left(-196{ }^{\circ} \mathrm{C}\right) \text {. }\end{array}$ & 6 months & 80 \\
\hline \multirow[b]{2}{*}{ H. ostrearia NCC-J $\mu 1$ [53] } & $\begin{array}{l}\text { Immobilization of cells in Ca-alginate gel and } \\
\text { dehydration in the presence of } 0.7 \mathrm{M} \text { sucrose solution } \\
\text { with further freezing in liquid nitrogen }\left(-196^{\circ} \mathrm{C}\right) \text {. }\end{array}$ & \multirow[b]{2}{*}{$48 \mathrm{~h}$} & $57.4 \pm 3.9$ \\
\hline & $\begin{array}{l}\text { Immobilization of cells in Ca-alginate gel and } \\
\text { dehydration in the presence of } 0.7 \mathrm{M} \text { sucrose solution. } \\
\text { Two-step freezing: freezing for } 1 \mathrm{~h} \text { at }-80^{\circ} \mathrm{C} \text { and then } \\
\text { quick transfer into liquid nitrogen }\left(-196^{\circ} \mathrm{C}\right) \text {. }\end{array}$ & & $76.9 \pm 3.3$ \\
\hline Oocystis sp. [58] & $\begin{array}{c}\text { Encapsulation in Ca-alginate microbeads with } \\
\text { addition of cryoprotectants supplemented with } \\
100(\mu \mathrm{M}) \text { glutathione at room temperature. } \\
\text { The algal-encapsulated microbeads were exposed to } \\
\text { equilibration solution }(15 \%(w / v) \text { glycerol, } 7.5 \%(w / v) \\
\text { ethylene glycol, } 7.5 \%(w / v) \text { dimethyl sulfoxide }) \\
\text { followed by vitrification solution }(30 \%(w / v) \text { glycerol, } \\
15 \%(w / v) \text { ethylene glycol, } 15 \%(w / v) \text { DMSO at } 27^{\circ} \mathrm{C} \\
\text { for } 0.5 \mathrm{~h} \text { and } 0.25 \text { h respectively. Freezing in liquid } \\
\text { nitrogen }\left(-196^{\circ} \mathrm{C}\right) \text {. }\end{array}$ & 14 days & $79 \pm 1.6$ \\
\hline
\end{tabular}


Table 4. Cont.

\begin{tabular}{cccc}
\hline Strain [Reference] & Cryopreservation of Biomass * & Storage Time & Cell Viability, \% \\
\hline $\begin{array}{c}\text { Rivularia aquatica and } \\
\text { Gloeotrichia echinulata [54] }\end{array}$ & $\begin{array}{c}\text { Cells were entrapped in Ca-alginate gel and } \\
\text { stored at }-20{ }^{\circ} \mathrm{C} .\end{array}$ & $\begin{array}{c}4 \text { year } \\
\text { respectively }\end{array}$ \\
\hline $\begin{array}{c}\text { C. vulgaris [Beier.] rsemsu } \\
\text { Chv-20/11 }\end{array}$ & Mixing with PVA solution and freezing at $-70{ }^{\circ} \mathrm{C}$. & 18 month \\
[This work] & *EG-ethylene glycol, DMSO-dimethyl sulfoxide. & & $90 \pm 5$ \\
\hline
\end{tabular}

An essential feature of the approach to cryoimmobilization and cryoconservation of microalgal cells that we tested is that freezing is performed in the same stage as the entrapment of the phototrophic microorganism cells in the polymeric cryogel, the latter playing the role of cryoprotectant at the same time [27].

It was established via a comparison of various techniques for cryoconservation of microalgal cells that the viability of cells cryoimmobilized in PVA cryogel was essentially higher than that used in many other techniques summarized in Table 4.

The results observed in this study, as well as the known data on the microalgal biomass accumulation upon cultivation in industrial wastewater of various types with the use of both suspended and immobilized inoculum cells are summarized in (Table 5). The productivity of immobilized cells in terms of biomass accumulated in wastewater was 30-70 mg CDW/L/d, which is 4-11 times lower than in the case of cells cryoimmobilized in PVA cryogel (311.3-407.3 mg CDW/L/d), which was used in the study (Table 5). Thus the inoculum based on C. vulgaris cells cryoimmobilized in the PVA cryogel was found to be effective for biomass accumulation in various media. Note that the cell growth rate was almost unchanged after at least 5 reuses of the inoculum granules.

Table 5. Biomass productivity of various species of Chlorella during cultivation of free and immobilized cells in wastewater from various sources.

\begin{tabular}{|c|c|c|c|}
\hline Strain & Cell Form & $\begin{array}{l}\text { Wastewater Source } \\
\text { [Reference] }\end{array}$ & $\begin{array}{c}\text { Biomass Productivity, mg } \\
\text { CDW/L/d }\end{array}$ \\
\hline C. saccharophila & Suspended & $\begin{array}{l}\text { Water from carpet industry with } \\
\text { municipal sewage [59] }\end{array}$ & 23.0 \\
\hline C. sorokiniana UTEX1230 & & $\begin{array}{l}\text { Municipal and domestic with } \\
\text { water supplemented } \mathrm{CO}_{2}[60]\end{array}$ & 82.5 \\
\hline C. vulgaris & & Aquaculturing [61] & 42.6 \\
\hline C. vulgaris SAG 211-11b & & Poultry litter [62] & 127.0 \\
\hline \multirow{3}{*}{ Chlorella sp. } & & Manure [63] & 90.0 \\
\hline & & \multirow[b]{2}{*}{ Artificial [64] } & 130.0 \\
\hline & $\begin{array}{l}\text { * Immobilized in polymeric } \\
\text { carrier NaCS-DMDAAC }\end{array}$ & & 55.0 \\
\hline \multirow{4}{*}{ C. vulgaris } & \multirow{4}{*}{$\begin{array}{l}\text { Immobilized on } \\
\text { poly(vinylidene fluoride) } \\
\text { hollow-fiber membrane }\end{array}$} & Municipal secondary effluent [65] & 72.0 \\
\hline & & Municipal water [66] & 39.9 \\
\hline & & Domestic secondary effluent [67] & 50.7 \\
\hline & & Aquaculturing [61] & 42.6 \\
\hline $\begin{array}{l}\text { C. vulgaris AG30007 + } \\
\text { activated sludge }\end{array}$ & Immobilized in Ca-alginate gel & Municipal wastes [68] & 50.0 \\
\hline
\end{tabular}


Table 5. Cont.

\begin{tabular}{|c|c|c|c|}
\hline Strain & Cell Form & $\begin{array}{c}\text { Wastewater Source } \\
\text { [Reference] }\end{array}$ & $\begin{array}{c}\text { Biomass Productivity, mg } \\
\text { CDW/L/d }\end{array}$ \\
\hline C. vulgaris ATCC 13482 & $\begin{array}{l}\text { Immobilized on } \\
\text { commercial thin film composite } \\
\text { membrane }\end{array}$ & Synthetic wastewater [69] & 31.0 \\
\hline Chlorella sp. ADE4 & $\begin{array}{l}\text { Immobilized on high-density } \\
\text { polyethylene hollow fiber } \\
\text { microfiltration membrane }\end{array}$ & Treated sewage effluent [70] & 55.0 \\
\hline \multirow{3}{*}{$\begin{array}{l}\text { C. vulgaris [Beier.] rsemsu } \\
\text { Chv-20/11 }\end{array}$} & \multirow{3}{*}{$\begin{array}{l}\text { Immobilized in } \\
\text { PVA cryogel }\end{array}$} & Horticultural wastes & $335.3 \pm 16.7$ \\
\hline & & Municipal wastes & $311.3 \pm 15.5$ \\
\hline & & $\begin{array}{l}\text { Milk plant wastes } \\
\text { [this work] }\end{array}$ & $407.3 \pm 20.3$ \\
\hline
\end{tabular}

* NaCS-DMDAAC—sodium cellulose sulphate/poly(dimethyl-diallyl-ammonium chloride).

Since it is known that microalgal cells can be used for continuous bioindicative monitoring of the presence of pollutants in waters to be discharged into environmental water systems, for example, after aquaculturing [6], then the use of microalgal cells immobilized in mechanically strong granules of PVA cryogel for these purposes can allow such control in the flow-through systems by analogy with previously developed bioanalytical sensors based on cells of luminous bacteria cells included in the PVA cryogel that have a bioluminescent reaction to ecotoxicants [71,72].

Phototrophic microorganisms are often the objects of research in connection with the study of their behavior during the blooming of natural reservoirs [73,74]. For such work, among other things, it is necessary to assess the concentrations of cells preceding a sharp jump in biomass accumulation, as well as the functional and metabolic activities of microalgae and cyanobacteria cells in high-density populations associated with the synthesis and secretion of toxic substances by these cells $[75,76]$.

This phenomenon provokes not only a reduction in water quality, but also causes direct damage to the environment or the creation of a serious environmental threat to various living objects.

The use of artificially immobilized inoculates in such studies can make it possible to simulate and help to study natural processes under laboratory conditions in order to predict and manage them, including preventing their possible ecological development with some negative impacts on the sustainable state of ecosystems. Thus, stable cryoimmobilized inocula providing accumulation of microalgal cells with reproducible characteristics can be useful in this case.

\section{Conclusions}

Thus, it was shown that due to the cryoimmobilization of cells of phototrophic microorganisms by including them in the PVA cryogel, it is possible to provide:

- Their cryopreservation and long-term storage, without the loss of functional, metabolic activity and basic biochemical characteristics of the cells, including in hereditary phototrophic cells.

- The use of immobilized cells as an inoculum for the accumulation of phototrophic cell biomass, including after long-term storage, under mixotrophic conditions, that allows combining wastewater treatment with the growth of microalgae, and accumulation of the phototrophic cell biomass for its conversion to various products in the frame of green chemistry and nature-like processes.

The created samples of cryoimmobilized phototrophic cells confirmed that in the environment of polymers (in this work synthetic, such as PVA, and in nature, biopolymers), the structuring of which occurs under the influence of multiple weak chemical interactions, 
microalgal cells can tolerate freezing/thawing processes under environmental conditions and can sustainably maintain their viability and ability to grow and reproduce.

Author Contributions: Conceptualization, E.E.; methodology, O.S., O.M. and N.S.; validation, O.S and N.S.; formal analysis, E.E. and O.M.; investigation, O.S. and N.S.; data curation, E.E.; writingoriginal draft preparation, O.S., N.S., O.M. and E.E.; writing-review and editing, O.S., N.S. and E.E.; visualization, N.S. and O.M.; supervision, E.E.; project administration, E.E. All authors have read and agreed to the published version of the manuscript.

Funding: This research was funded by State Task No.1201253312 of the Institute of Biochemical Physics Russian Academy of Science (Part 47.11 Chemical aspects of energetic) in a part of obtaining cryoimmobilized microalgal cells. The research was funded by State Task of Lomonosov Moscow State University (AAAA-A21-121041500039-8) in a part of using wastewater various type of purification by the use of immobilized microalgal cells.

Institutional Review Board Statement: Not applicable.

Informed Consent Statement: Not applicable.

Data Availability Statement: The data presented in this study are available by request.

Acknowledgments: This research was performed according to the Development program of the Interdisciplinary Scientific and Educational School of Lomonosov Moscow State University "The future of the planet and global environmental change". This study was made possible through the support of the Applied Genetics Resource Facility of the Moscow Institute of Physics and Technology (MIPT).

Conflicts of Interest: The authors declare no conflict of interest.

\section{References}

1. Tan, J.S.; Lee, S.Y.; Chew, K.W.; Lam, M.K.; Lim, J.W.; Ho, S.-H.; Show, P.L. A review on microalgae cultivation and harvesting, and their biomass extraction processing using ionic liquids. Bioengineered 2020, 11, 116-129. [CrossRef] [PubMed]

2. Khan, M.I.; Shin, J.H.; Kim, J.D.; Khan, M.I.; Shin, J.H.; Kim, J.D. The promising future of microalgae: Current status, challenges, and optimization of a sustainable and renewable industry for biofuels, feed, and other products. Microb. Cell Factories 2018, 17, 36. [CrossRef]

3. Sathasivam, R.; Radhakrishnan, R.; Hashem, A.; Abd_Allah, E.F. Microalgae metabolites: A rich source for food and medicine. Saudi J. Biol. Sci. 2019, 26, 709-722. [CrossRef]

4. Efremenko, E.N.; Nikolskaya, A.B.; Lyagin, I.V.; Sen'Ko, O.V.; Makhlis, T.A.; Stepanov, N.A.; Maslova, O.V.; Mamedova, F.; Varfolomeev, S.D. Production of biofuels from pretreated microalgae biomass by anaerobic fermentation with immobilized Clostridium acetobutylicum cells. Bioresour. Technol. 2012, 114, 342-348. [CrossRef]

5. Kokkinos, K.; Karayannis, V.; Moustakas, K. Optimizing Microalgal Biomass Feedstock Selection for Nanocatalytic Conversion Into Biofuel Clean Energy, Using Fuzzy Multi-Criteria Decision Making Processes. Front. Energy Res. 2021, 8, 622210. [CrossRef]

6. O'Neill, E.A.; Neil, J.R. Microalgae as a natural ecological bioindicator for the simple real-time monitoring of aquaculture wastewater quality including provision for assessing impact of extremes in climate variance: A comparative case study from the Republic of Ireland. Sci. Total Environ. 2022, 802, 149800. [CrossRef]

7. van den Broek, L.A.M.; Wagemakers, M.J.M.; Verschoor, A.M.; Frissen, A.E.; van Haveren, J.; Blaauw, R.; Mooibroek, H Microalgae as Renewable Raw Material for Bioproducts: Identification and Biochemical Composition of Microalgae from a Raceway Pond in The Netherlands. In Biomass as Renewable Raw Material to Obtain Bioproducts of High-Tech Value, 1st ed.; Popa, V., Volf, I., Eds.; Elsevier: Amsterdam, The Netherlands, 2018; pp. 39-68. [CrossRef]

8. Udaiyappan, A.F.M.; Abu Hasan, H.; Takkriff, M.S.; Abdullah, S.R.S. A review of the potentials, challenges and current status of microalgae biomass applications in industrial wastewater treatment. J. Water Process Eng. 2017, 20, 8-21. [CrossRef]

9. Lam, M.K.; Yusoff, M.I.; Uemura, Y.; Lim, J.-W.; Khoo, C.G.; Lee, K.T.; Ong, H.C. Cultivation of Chlorella vulgaris using nutrients source from domestic wastewater for biodiesel production: Growth condition and kinetic studies. Renew. Energy 2017, 103, 197-207. [CrossRef]

10. Ahmad, A.; Bhat, A.H.; Buang, A. Immobilized Chlorella vulgaris for efficient palm oil mill effluent treatment and heavy metals removal. Desalinisation Water Treat. 2017, 81, 105-117. [CrossRef]

11. Makhlis, T.A.; Senko, O.V.; Mamedova, F.T.; Efremenko, E.N. Immobilization of cells as approach to their long-term storage. In Immobilized Cells: Biocatalysts and Processes; Efremenko, E.N., Ed.; RIOR: Moscow, Russia, 2018; pp. 97-122.

12. Vasilieva, S.G.; Lobakova, E.S.; Lukyanov, A.A.; Solovchenko, A.E. Immobilized microalgae in biotechnology. Mosc. Univ. Biol. Sci. Bull. 2016, 71, 170-176. [CrossRef]

13. Xiao, R.; Zheng, Y. Overview of microalgal extracellular polymeric substances (EPS) and their applications. Biotechnol. Adv. 2016, 34, 1225-1244. [CrossRef] [PubMed] 
14. Ray, A.; Banerjee, S.; Das, D. Microalgal bio-flocculation: Present scenario and prospects for commercialization. Environ. Sci. Pollut. Res. 2021, 28, 26294-26312. [CrossRef]

15. Osorio, J.H.M.; Pollio, A.; Frunzo, L.; Lens, P.N.L.; Esposito, G. A Review of Microalgal Biofilm Technologies: Definition, Applications, Settings and Analysis. Front. Chem. Eng. 2021, 3, 737710. [CrossRef]

16. Caldwell, G.S.; In-Na, P.; Hart, R.; Sharp, E.; Stefanova, A.; Pickersgill, M.; Walker, M.; Unthank, M.; Perry, J.; Lee, J. Immobilising Microalgae and Cyanobacteria as Biocomposites: New Opportunities to Intensify Algae Biotechnology and Bioprocessing. Energies 2021, 14, 2566. [CrossRef]

17. Ng, F.-L.; Phang, S.-M.; Vengadesh, P.; Periasamy, V.; Yunus, K.; Fisher, A.C. Enhancement of Power Output by using Alginate Immobilized Algae in Biophotovoltaic Devices. Sci. Rep. 2017, 7, 16237. [CrossRef]

18. Lozinsky, V.I. Cryostructuring of Polymeric Systems. 50. Cryogels and Cryotropic Gel-Formation: Terms and Definitions. Gels 2018, 4, 77. [CrossRef]

19. Podorozhko, E.A.; Buzin, M.I.; Golubev, E.K.; Shcherbina, M.A.; Lozinsky, V.I. A Study of Cryostructuring of Polymer Systems 59. Effect of Cryogenic Treatment of Preliminarily Deformed Poly(vinyl alcohol) Cryogels on Their Physicochemical Properties. Colloid J. 2021, 83, 634-641. [CrossRef]

20. Senko, O.; Gladchenko, M.; Maslova, O.; Efremenko, E. Long-Term Storage and Use of Artificially Immobilized Anaerobic Sludge as a Powerful Biocatalyst for Conversion of Various Wastes Including Those Containing Xenobiotics to Biogas. Catalysts 2019, 9 , 326. [CrossRef]

21. Stepanov, N.; Efremenko, E. “Deceived” Concentrated Immobilized Cells as Biocatalyst for Intensive Bacterial Cellulose Production from Various Sources. Catalysts 2018, 8, 33. [CrossRef]

22. Maslova, O.; Stepanov, N.; Senko, O.; Efremenko, E. Production of various organic acids from different renewable sources by immobilized cells in the regimes of separate hydrolysis and fermentation (SHF) and simultaneous saccharification and fermentation (SFF). Bioresour. Technol. 2019, 272, 1-9. [CrossRef]

23. Efremenko, E.N.; Tatarinova, N.Y. The effect of long-term preservation of bacterial cells immobilized in poly(vinyl alcohol) cryogel on their viability and biosynthesis of target metabolites. Microbiology 2007, 76, 336-341. [CrossRef]

24. Razumovsky, S.D.; Efremenko, E.N.; Makhlis, T.A.; Senko, O.V.; Bikhovsky, M.Y.; Podmaster'Ev, V.V.; Varfolomeev, S.D. Effect of immobilization on the main dynamic characteristics of the enzymatic oxidation of methane to methanol by bacteria Methylosinus sporium B-2121. Russ. Chem. Bull. 2008, 57, 1633-1636. [CrossRef]

25. Ali, P.; Fucich, D.; Shah, A.A.; Hasan, F.; Chen, F. Cryopreservation of Cyanobacteria and Eukaryotic Microalgae Using Exopolysaccharide Extracted from a Glacier Bacterium. Microorganisms 2021, 9, 395. [CrossRef]

26. Kapoore, R.V.; Huete-Ortega, M.; Day, J.G.; Okurowska, K.; Slocombe, S.P.; Stanley, M.S.; Vaidyanathan, S. Effects of cryopreservation on viability and functional stability of an industrially relevant alga. Sci. Rep. 2019, 9, 2093. [CrossRef]

27. Nowshari, M.A.; Brem, G. The protective action of polyvinyl alcohol during rapid-freezing of mouse embryos. Theriogenology 2000, 53, 1157-1166. [CrossRef]

28. Cunningham, C.J.; Ivshina, I.B.; Lozinsky, V.I.; Kuyukina, M.S.; Philp, J.C. Bioremediation of diesel-contaminated soil by microorganisms immobilised in polyvinyl alcohol. Int. Biodeterior. Biodegrad. 2004, 54, 167-174. [CrossRef]

29. Kumar, A. Supermacroporous Cryogels: Biomedical and Biotechnological Application; CRC Press: New York, NY, USA, 2016.

30. Stepanov, N.; Efremenko, E. Immobilised cells of Pachysolen tannophilus yeast for ethanol production from crude glycerol. New Biotechnol. 2017, 34, 54-58. [CrossRef]

31. Matsunaga, N.; Uehara, A.; Murase, N.; Kuriyama, A. Cryopreservation of Spirulina (Arthrospira) platensis NIES-46 by snapfreezing considering trichome morphology. Cryobiol. Cryotechnol. 2019, 64, 75-83. [CrossRef]

32. Shiraishi, H. Cryopreservation of the edible alkalophilic cyanobacterium Arthrospira platensis. Biosci. Biotechnol. Biochem. 2016, 80, 2051-2057. [CrossRef]

33. Prasad, R.N.; Sanghamitra, K.; Antonia, G.-M.; Juan, G.-V.; Benjamin, R.-G.; Luis, I.-M.J.; Guillermo, V.-V. Isolation, Identification and Germplasm Preservation of Different Native Spirulina Species from Western Mexico. Am. J. Plant Sci. 2013, $04,65-71$. [CrossRef]

34. Iwamoto, K.; Fukuyo, S.; Okuda, M.; Kobayashi, M.; Shiraiwa, Y. Cryopreservation of the Chlorophyll d-Containing Cyanobacterium Acaryochloris Marina. Procedia Environ. Sci. 2012, 15, 118-125. [CrossRef]

35. Mori, F.; Erata, M.; Watanabe, M.M. Cryopreservation of cyanobacteria and green algae in the NIES-collection. Microbiol. Cult. Coll. 2002, 18, 45-55.

36. Motham, M.; Peerapornpisal, Y.; Tongsriri, S.; Pumas, C.; Vacharapiyasophon, P. High subzero temperature preservation of Spirulina platensis (Spirulina fusiformis) and its ultrastructure. Chiang Mai J. Sci. 2012, 39, 554-561. Available online: https:/ / www.thaiscience.info/journals/Article/CMJS/10905239.pdf (accessed on 4 January 2022).

37. Efremenko, E.N.; Senko, O.V.; Makhls, T.A.; Mamedova, F.T.; Holstov, A.V.; Varfolomeev, S.D. Method of Cryopreservation Phototrophic Microorganisms Cells. RU Patent 2508397, 27 February 2014.

38. Araujo, G.S.; Matos, L.J.; Fernandes, J.O.; Cartaxo, S.J.; Gonçalves, L.R.; Fernandes, F.A.; Farias, W.R. Extraction of lipids from microalgae by ultrasound application: Prospection of the optimal extraction method. Ultrason. Sonochem. 2013, 20, 95-98. [CrossRef] [PubMed]

39. ISO 6060:1989 Water Quality—Determination of the Chemical Oxygen Demand. Available online: https://www.iso.org/obp/ui/ \#iso:std:iso:6060:ed-2:v1:en (accessed on 4 January 2022). 
40. ISO 11905-1:1997 Water Quality—Determination of Nitrogen—Part 1: Method Using Oxidative Digestion with Peroxodisulfate. Available online: https://www.iso.org/obp/ui/\#iso:std:iso:11905:-1:ed-1:v1:en (accessed on 4 January 2022).

41. ISO 11923:1997 Water Quality-Determination of Suspended Solids by Filtration through Glass-Fibre Filters, APHA, AWWA, WEF. Standard Methods for Examination of Water and Wastewater. Available online: https://www.iso.org/obp/ui/fr/\#iso:std: iso:11923:ed-1:v1:en (accessed on 4 January 2022).

42. ISO 6878:2004 Water Quality-Determination of Phosphorus-Ammonium Molybdate Spectrometric Method. Available online: https:/ / www.iso.org/obp/ui/\#iso:std:iso:6878:ed-2:v1:en (accessed on 4 January 2022).

43. Fursova, P.V.; Bobyrev, P.A.; Risnik, D.V.; Voronova, E.N.; Pogosyan, S.I. Bioindicational Potential of Biophysical and Hydrobiological Indicators of Phytoplankton in Experiments with Laboratory Algocenoses. Biol. Bull. Rev. 2020, 10, 193-201. [CrossRef]

44. Andres, A.I.; Petron, M.J.; Lopez, A.M.; Timon, M.L. Optimization of Extraction Conditions to Improve Phenolic Content and In Vitro Antioxidant Activity in Craft Brewers' Spent Grain Using Response Surface Methodology (RSM). Foods 2020, 9, 1398. [CrossRef]

45. Breuer, G.; Evers, W.A.C.; De Vree, J.H.; Kleinegris, D.M.M.; Martens, D.E.; Wijffels, R.H.; Lamers, P.P. Analysis of Fatty Acid Content and Composition in Microalgae. J. Vis. Exp. 2013, e50628. [CrossRef]

46. Bohutskyi, P.; Kligerman, D.C.; Byers, N.; Nasr, L.K.; Cua, C.; Chow, S.; Su, C.; Tang, Y.; Betenbaugh, M.J.; Bouwer, E.J. Effects of inoculum size, light intensity, and dose of anaerobic digestion centrate on growth and productivity of Chlorella and Scenedesmus microalgae and their poly-culture in primary and secondary wastewater. Algal Res. 2016, 19, 278-290. [CrossRef]

47. Supraja, K.V.; Behera, B.; Balasubramanian, P. Performance evaluation of hydroponic system for co-cultivation of microalgae and tomato plant. J. Clean. Prod. 2020, 272, 122823. [CrossRef]

48. Prakash, J.; Kalia, V.C. Application of Quorum Sensing Systems in Production of Green Fuels. In Quorum Sensing and Its Biotechnological Applications; Kalia, V.P., Ed.; Springer: Singapore, 2018; pp. 155-166. [CrossRef]

49. Rincon, S.M.; Romero, H.M.; Aframehr, W.M.; Beyenal, H. Biomass production in Chlorella vulgaris biofilm cultivated under mixotrophic growth conditions. Algal Res. 2017, 26, 153-160. [CrossRef]

50. Herrera, N.; Echeverri, F. Evidence of Quorum Sensing in Cyanobacteria by Homoserine Lactones: The Origin of Blooms. Water 2021, 13, 1831. [CrossRef]

51. Chi, W.; Zheng, L.; He, C.; Han, B.; Zheng, M.; Gao, W.; Sun, C.; Zhou, G.; Gao, X. Quorum sensing of microalgae associated marine Ponticoccus sp. PD-2 and its algicidal function regulation. AMB Express 2017, 7, 59. [CrossRef]

52. Dow, L. How Do Quorum-Sensing Signals Mediate Algae-Bacteria Interactions? Microorganisms 2021, 9, 1391. [CrossRef]

53. Tanniou, A.; Turpin, V.; Lebeau, T. Comparison of cryopreservation methods for the long term storage of the marine diatom Haslea ostrearia (simonsen). Cryobiology 2012, 65, 45-50. [CrossRef]

54. Choudhary, K.K. Post-storage viability and metabolic stability of immobilized cyanobacteria. Nova Hedwig. 2010, 90, 215-226. [CrossRef]

55. Morschett, H.; Reich, S.; Wiechert, W.; Oldiges, M. Simplified cryopreservation of the microalga Chlorella vulgaris integrating a novel concept for cell viability estimation. Eng. Life Sci. 2016, 16, 36-44. [CrossRef]

56. Nakanishi, K.; Deuchi, K.; Kuwano, K. Cryopreservation of four valuable strains of microalgae, including viability and characteristics during 15 years of cryostorage. J. Appl. Phycol. 2012, 24, 1381-1385. [CrossRef]

57. Saadaoui, I.; Al Emadi, M.; Bounnit, T.; Schipper, K.; Al Jabri, H. Cryopreservation of microalgae from desert environments of Qatar. J. Appl. Phycol. 2015, 28, 2233-2240. [CrossRef]

58. Kumari, N.; Gupta, M.K.; Singh, R.K. Open encapsulation-vitrification for cryopreservation of algae. Cryobiology 2016, 73, 232-239. [CrossRef]

59. Chinnasamy, S.; Bhatnagar, A.; Hunt, R.W.; Das, K.C. Microalgae cultivation in a wastewater dominated by carpet mill effluents for biofuel applications. Bioresour. Technol. 2010, 101, 3097-3105. [CrossRef]

60. Lizzul, A.M.; Hellier, P.; Purton, S.; Baganz, F.; Ladommatos, N.; Campos, L. Combined remediation and lipid production using Chlorella sorokiniana grown on wastewater and exhaust gases. Bioresour. Technol. 2014, 151, 12-18. [CrossRef]

61. Gao, F.; Li, C.; Yang, Z.-H.; Zeng, G.-M.; Feng, L.-J.; Liu, J.-Z.; Liu, M.; Cai, H.-W. Continuous microalgae cultivation in aquaculture wastewater by a membrane photobioreactor for biomass production and nutrients removal. Ecol. Eng. 2016, 92, 55-61. [CrossRef]

62. Markou, G. Fed-batch cultivation of Arthrospira and Chlorella in ammonia-rich wastewater: Optimization of nutrient removal and biomass production. Bioresour. Technol. 2015, 193, 35-41. [CrossRef]

63. Wang, L.; Li, Y.; Chen, P.; Min, M.; Chen, Y.; Zhu, J.; Ruan, R.R. Anaerobic digested dairy manure as a nutrient supplement for cultivation of oil-rich green microalgae Chlorella sp. Bioresour. Technol. 2010, 101, 2623-2628. [CrossRef]

64. Zeng, X.; Danquah, M.K.; Zheng, C.; Potumarthi, R.; Chen, X.D.; Lu, Y. NaCS-PDMDAAC immobilized autotrophic cultivation of Chlorella sp. for wastewater nitrogen and phosphate removal. Chem. Eng. J. 2012, 187, 185-192. [CrossRef]

65. Gao, F.; Yang, Z.-H.; Li, C.; Zeng, G.-M.; Ma, D.-H.; Zhou, L. A novel algal biofilm membrane photobioreactor for attached microalgae growth and nutrients removal from secondary effluent. Bioresour. Technol. 2015, 179, 8-12. [CrossRef]

66. Gao, F.; Yang, Z.-H.; Li, C.; Wang, Y.-J.; Jin, W.-H.; Deng, Y.-B. Concentrated microalgae cultivation in treated sewage by membrane photobioreactor operated in batch flow mode. Bioresour. Technol. 2014, 167, 441-446. [CrossRef] 
67. Gao, F.; Li, C.; Yang, Z.-H.; Zeng, G.-M.; Mu, J.; Liu, M.; Cui, W. Removal of nutrients, organic matter, and metal from domestic secondary effluent through microalgae cultivation in a membrane photobioreactor. J. Chem. Technol. Biotechnol. 2016, 91, 2713-2719. [CrossRef]

68. Mujtaba, G.; Lee, K. Treatment of real wastewater using co-culture of immobilized Chlorella vulgaris and suspended activated sludge. Water Res. 2017, 120, 174-184. [CrossRef]

69. Praveen, P.; Loh, K.-C. Nitrogen and phosphorus removal from tertiary wastewater in an osmotic membrane photobioreactor. Bioresour. Technol. 2016, 206, 180-187. [CrossRef]

70. Boonchai, R.; Seo, G. Microalgae membrane photobioreactor for further removal of nitrogen and phosphorus from secondary sewage effluent. Korean J. Chem. Eng. 2015, 32, 2047-2052. [CrossRef]

71. Senko, O.; Stepanov, N.; Maslova, O.; Akhundov, R.; Ismailov, A.; Efremenko, E. Immobilized Luminescent Bacteria for the Detection of Mycotoxins under Discrete and Flow-Through Conditions. Biosensors 2019, 9, 63. [CrossRef]

72. Efremenko, E.N.; Maslova, O.V.; Kholstov, A.V.; Senko, O.V.; Ismailov, A.D. Biosensitive element in the form of immobilized luminescent photobacteria for detecting ecotoxicants in aqueous flow-through systems. Luminescence 2016, 31, 1283-1289. [CrossRef] [PubMed]

73. Khesina, Z.B.; Karnaeva, A.E.; Pytskii, I.S.; Buryak, A.K. The mysterious mass death of marine organisms on the Kamchatka Peninsula: A consequence of a technogenic impact on the environment or a natural phenomenon? Mar. Pollut. Bull. 2021, 166, 112175. [CrossRef] [PubMed]

74. Zohdi, E.; Abbaspour, M. Harmful algal blooms (red tide): A review of causes, impacts and approaches to monitoring and prediction. Int. J. Environ. Sci. Technol. 2019, 16, 1789-1806. [CrossRef]

75. Zingone, A.; Escalera, L.; Aligizaki, K.; Fernández-Tejedor, M.; Ismael, A.; Montresor, M.; Mozetič, P.; Taş, S.; Totti, C. Toxic marine microalgae and noxious blooms in the Mediterranean Sea: A contribution to the Global HAB Status Report. Harmful Algae 2021, 102, 101843. [CrossRef] [PubMed]

76. Tester, P.A.; Litaker, R.W.; Berdalet, E. Climate change and harmful benthic microalgae. Harmful Algae 2020, 91, 101655. [CrossRef] [PubMed] 